\title{
技術報告
}

\section{マイクロコンピューター制御型電気分析システムによる 微分パルスポーラログラフィーと，そのデータ処理}

\author{
和佐 保®，山本 弘，秋元 健吾*
}

\author{
(1982 年 7 月 26 日受理)
}

\begin{abstract}
2 台のマイクロコンピューター (MEK DII，Motorola 及び H68/TR，日立) とアナログ電解・測 定部より成る電気分析システムを試作し, 微分パルスポーラログラフィーのための装置制御及びデータ 処理プログラムの開発を行った．解析処理プログラムはピークの検出， 2 次多項式によるバックグラウ ンド補正，最小二乗カーブフィッティング法によるピーク電流 $\left(I_{\mathrm{p}}\right)$, ピーク電位 $\left(E_{\mathrm{p}}\right)$, 半值幅 $\left(W_{\mathrm{p}}\right)$ の算出部より構成されており，BASIG 語で記述されている. $10 \mu \mathrm{M}$ レベルの実際試料（ピラジン， $\mathrm{Pb}^{2+}, \mathrm{Cd}^{2+}, \mathrm{Zn}^{2+}$ など）の分析に対するシステムの総合精度は， $I_{\mathrm{p}}$ について $2 \%, E_{\mathrm{p}}$ について $1 \%, W_{\mathrm{p}}$ について $5 \%$ 以内であり, 又処理時間は 1 ピーク当たり（1〜2）分であった. 更に，力ー ブフィッティングに用いる関数系（ポーラログラフィーの理論式，ガウス及びローレンッ関数）につい て基礎的考察を試みた。
\end{abstract}

\section{1 緒言}

Heyrovský-志方によって開発された直流 ポーラログ ラフィーは, 各種のパルス技法の導入により, く形波及 び微分パルスポーラログラフィー, 各種溶出ボルタンメ トリーなどの高感度分析法として発展してきた1). しか し, これらの測定方法では複雑な加電圧波形とタイミン グ制御を必要とするため, アナログ回路のみでとのすべ てを実現できる多目的装置を組み立てることは装置が極 めて複雑となり, 経費面のみならず操作性の面からも得 策とはいえない2).

これらの難点を解決するため，ミニコンピューターを 導入してポテンショスタットの制御とデータ集録の大部 分をソフトウェアで分担させることにより, 比較的簡単 なアナログ電解・測定部を用いて各種の測定が容易に実 現できるようになった ${ }^{3) \sim 6)}$. 更に, 最近ではマイクロコ ンピューター（以下，マイコンと略記）の普及に伴い, 高価なミニコンピューターに代わってマイコンを用いる 装置の試作 ${ }^{27}$ 7) 99) とその応用研究10)11)が盛んに行われる よらになってきた.

著者らは前報 ${ }^{12)} に w^{2} い て ， 2$ 台のマイコンとポテンシ

* 大阪府立大学工学部応用化学教室 : 大阪府堺市百舌 鳥梅町 4-804
ョスタットを有機的に組み合わせた電解測定・データ処 理システムの試作と，タスト及びノルマルパルスポーラ ログラフィーへの応用について報告した. 本報では, 微 分パルスポーラログラフィーへの応用と解析処理プログ ラムの開発，及びその実用性について検討した結果を報 告する.

\section{2 実験}

\section{1 ハードウエア}

アナログ電解・測定部, 制御・データ集録部（マイコ ソ I : MEK DII, Motorola) 及びデータ処理部（マイ コン II : H68/TR, 日立）の 3 部より成る既報の試作 システムを使用した12).

\section{2 ソフトウェア}

2.2.1 制御・データ集録プログラム 制御・データ 集録用プログラムは，M6800 用機械語で作成した 既報 のプログラム ${ }^{12)} に$, 積算平均及びノイズ除去機能を付加 して使用した（主プログラム：512 bytes；ノイズ除去 プログラム : 140 bytes ; データ : 256 bytes). 高感度測 定時に現れるキャピラリーノイズ13)やポップコーンノイ ズ14)の妨害を除去し， かつ市販装置で見られる RC フ ィルター $\{\tau=(100 \sim 1000) \mathrm{ms}\}$ による追従の遅れ15)を避 
けるため，積算平均及びノイズ除去プログラムを開発し た. 前者は同電位で $n$ 回測定し加算平均する方法であ り，後者ではデータとして採用するばらつきの範用 $r$ \{フルスケールの $(1 \sim 10) \%\}$ と測定回数 $n \quad\{(2 \sim 10)$ 回 $\}$ を設定し， $r$ の範囲内にある $n$ 回の平均值をメモり 一に集録する方法を用いた. 後者はノイズ除去に極めて 優れた効果を示すが，ｒが小さすぎると測定に長時間を 要するため, ノイズ状態によって $r$ と $n$ を適度に設定す るよう留意する必要があった.

2.2.2 データ 処理プログラム ミニコンピュータ 一による電流・電位曲線の 解析方法については種々提 案4)616)17) されているが，その多くは実験者の助けを必 要とする 会話方式が 中心となり, 波の検出から解析処 理まで自動的に行ら方法46) は比較的少ない. 著者らは 先にシグモイド形ポーラログラムのマイコンによる自動 解析プログラムを開発し，その実用性について考察し た ${ }^{12)}$. 今回はピーク形ポーラログラムの自動解析プログ ラムについて概略を説明する.

BASIC 言語で書かれたプログラムのフローチャート を Fig. 1 に示す（プログラムエリア： 17.1 kbytes; 変数エリア： 11.6 kbytes). マイコンIから転送されて

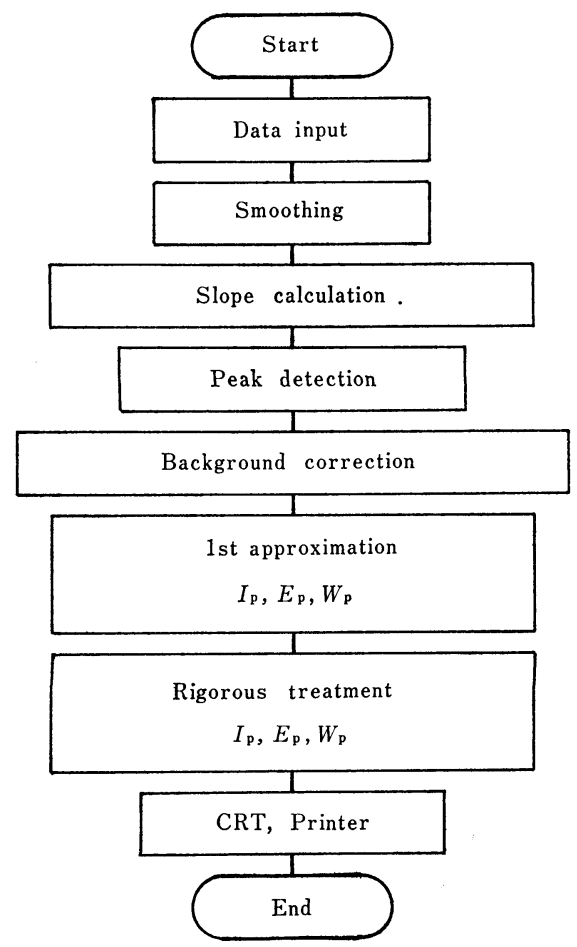

Fig. 1 Flow chart of data-processing program for differential pulse polarography
きたデータは平滑化 (Smoothing) の後, 各測定点の傾 斜 (Slope) を算出する. 平滑化データについて電流值比 較法によってピーク電位 $\left(E_{\mathrm{p}}\right)$ を決定し， $E_{\mathrm{p}}$ の両側の 各測定点の傾斜から変曲点を検出する. この変曲点間の 電位差をピーク幅 $(W)$ として, その $(3 \sim 4)$ 倍をピー ク領域とする (Peak detection). ピークの半值幅 $\left(W_{\mathrm{p}}\right)$ は, $W_{\mathrm{p}}=1.177 \times W$ で与えられる. 次にピーク領域の 外側 $(5 \sim 20)$ 点を用いて, 2 次多項式 (1) による最小 二乗フィッティング法（4 次多項式まで可能）によって バックグラウンド電流 $I_{\mathrm{b}}$ を求め, バックグラウンド補 正電流值 $Y_{\mathrm{i}}$ を算出し, ピーク電流 $\left(I_{\mathrm{p}}\right)$ を決定する.

$$
I_{\mathrm{b}}=A E_{\mathrm{i}}^{2}+B E_{\mathrm{i}}+C
$$

ここで, $E_{\mathrm{i}}$ は電位， $I_{\mathrm{b}}$ は電位 $E_{\mathrm{i}}$ におけるバックグ ラウンド電流, $A, B, C$ は定数である.

上記の操作を全測定領域について行い，すべてのピー クについて $I_{\mathrm{p}}, E_{\mathrm{p}}, W_{\mathrm{p}}$ を決定する (1st approximation). 次に, $Y_{\mathrm{i}}$ にいて, 上記の近似值を初期値とす るガウス関数 (2) による最小二乗カーブフィッティン グ法を行い $I_{\mathrm{p}}, E_{\mathrm{p}}, W_{\mathrm{p}}$ についての最適合値を算出し (Rigorous treatment), 近似值とともにテレビモニター (CRT) 及びプリンターに出力する.

$$
\begin{aligned}
Y\left(E_{\mathrm{i}}\right)= & I_{\mathrm{p}} \exp \left\{-0.5\left[\left(E_{\mathrm{i}}-E_{\mathrm{p}}\right) /\left(W_{\mathrm{p}} / 2\right.\right.\right. \\
& \left.\times 1.177)]^{2}\right\} \quad \ldots \ldots \ldots \ldots \ldots \ldots \ldots \ldots \ldots \ldots \ldots \ldots \ldots \ldots \ldots \ldots \ldots
\end{aligned}
$$

ここで $Y\left(E_{\mathrm{i}}\right)$ は電位 $E_{\mathrm{i}}$ における電流值である.

今回のプログラムでは非線形パラメーターの推定方法 として最小二乗 Taylor 微分補正法18)19)を, 行列式の計 算には Cramer 法 ${ }^{18)}$ を用いた。

\section{3 試薬及び電解セル}

ピラジン貯蔵液 : ピラジン (1,4-diazine, 和光純蒋 製) を蒸留水に溶解し $10 \mathrm{mM}\left(=10 \mathrm{~mol} \mathrm{~m}^{-3}\right)$ 水溶液を 調製した．金属イオン貯蔵液：鉛，カドミウム及び带鉛 の硝酸塩 (和光純薬製, 特級) を蒸留水に溶解し $10 \mathrm{mM}$ 水溶液を調製し, EDTA で標定した（ファクター：鈶， 1.047; カドミウム, 1.009; 亜鉛, 1.122).

電解セルとしてガラスフィルターと硝酸 カリウム-寒 天橋で液絡した 3 室電解セルを用い, 作用電極に滴下水 銀電極 $(m=0.507 \mathrm{mg} / \mathrm{s}, h=55 \mathrm{~cm})$ を, 参照電極に飽 和カロメル電極, 対極に白金線コイル $(0.5 \mathrm{~mm} \times 15 \mathrm{~cm})$ を使用した. 除酸素には窒素を用い, 測定は常法に従っ た. 


\section{3 結果及び考察}

\section{1 微分パルスポーラログラムの 記録 とコンピュー タ一解析}

$10 \mu \mathrm{M}$ 鈶，カドミウム，亜鉛イオンを含む電解液につ いての微分パルスポーラログラムの一例を Fig. 2 飞示 す.（a）は測定と同時に 記録したポーラログラムであ ク,（b）はメモリー上に集録したデータをDA 変換器 を通じてレコーダーに出力した結果である．Fig. 3 に は, 上記のポーラログラムを解析した場合のプリンター 出力の一例を示す. 出力リストは, コメント文, 測定と 解析条件, 出力形式と単位説明, 解析結果, 解析に用い た数值パラメーターから構成されている.もし，ピーク 領域に重なりを生じた場合は, “This peak is overlapped”とコメントを付してかっこ内の近似值のみを出力 し, カーブフィッティングは行わない，又測定データは ディジタルカセットに保存し, 必要に応じて迅速に検 索・再現できるようにした.

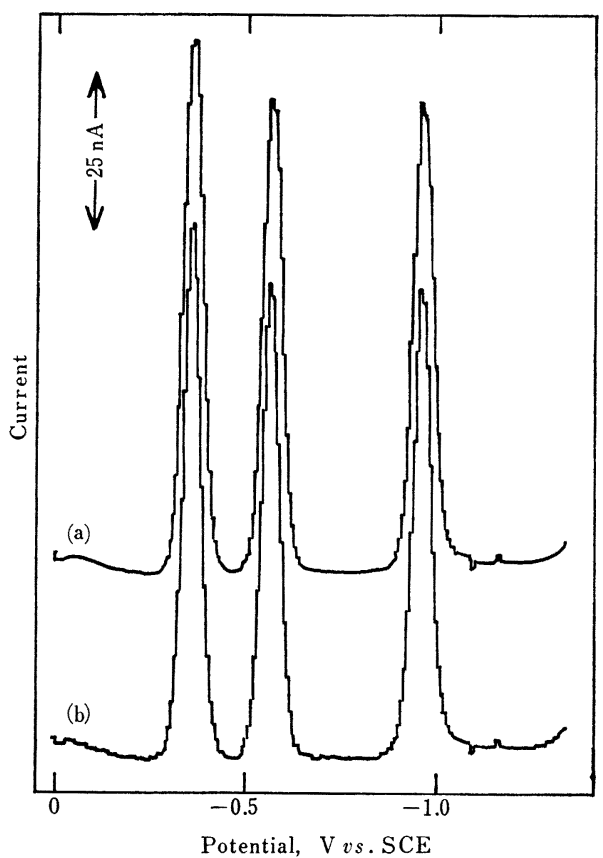

Fig. 2 Differential pulse polarograms of $10 \mu \mathrm{M}$ $\mathrm{Pb}^{2+}, \mathrm{Cd}^{2+}$, and $\mathrm{Zn}^{2+}$ in $0.1 \mathrm{M} \mathrm{KGl}$

(a) Polarogram obtained by direct recording-drop time $=1 \mathrm{~s}$, scan rate $=7.81 \mathrm{mV} / \mathrm{s}$, pulse height $=39.1$ $\mathrm{mV}$; (b) Polarogram regenerated from digitalized data

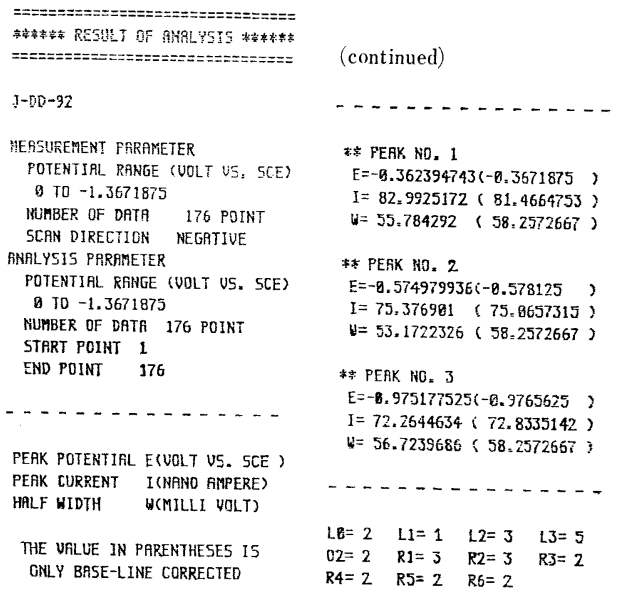

Fig. 3 A result of computer analysis for differential pulse polarogram of $10 \mu \mathrm{M} \mathrm{Pb}^{2+}$, $\mathrm{Cd}^{2+}$, and $\mathrm{Zn}^{2+}$ in $0.1 \mathrm{M} \mathrm{KGl}$

\section{2 バックグラウンド電流の補正と解析の正確さ}

式 (1)，式 (2) 及びノイズ電流 $\{\mathrm{N}(P, Q) ;$ ここ でPはノイズの出現確率，Qはノイズの最大值\}を用い て合成した電流・電位曲線 $\left(I_{\mathrm{p}}=1000 \mathrm{nA}, E_{\mathrm{p}}=-0.5\right.$ $\left.\mathrm{V}, W_{\mathrm{p}}=50 \mathrm{mV}\right)$ について解析を行った場合の結果を Table 1 飞示す. 式 (1) のパラメーターとして $(A=$ 6600, $B=-1015, C=1000),(A=0, B=-1015, C=0)$ 及び（ $A=0, B=0, C=0)$ を用いたとき，ピーク電位 に怙けるバックグラウンド電流とピーク電流の比 $\left(I_{\mathrm{b}} / I_{\mathrm{p}}\right)$ は 3.2, 0.5, 0 となり, それぞれ高感度, 中感度及び 低感度で測定した場合に得られる電流・電位曲線を代表 するものと仮定した. 又, ノイズ電流の最大值はピーク 電流の $10 \%$ とし,ノイズの大きさと発生時期はマイコ ンの乱数発生機能により制御した.

O* はバックグラウンド電流の補正に用いた多項式の 次数を示す. 2 次多項式で発生させたバックグラウンド 電流を 1 次式で補正した場合は比較的大きい誤差が認め られるが， 2 次又は 3 次式で補正することによって正確 な結果が得られた，実際のポーラログラムでは 2 次式で 良好な結果が得られること, 及び 3 次以上の高次多項式 を用いた場合補正曲線がピーク状になり大きな誤差を生

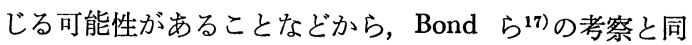
様に実用的には 2 次多項式が適当と考兄られる.

ノイズ電流を含む電流・電位曲線についての Table 1 の結果 (10 回の解析の平均值, かっこ内は変動係数) は, 強度のノイズが存在する場合 $I_{\mathrm{p}}$ と $W_{\mathrm{p}}$ に相当大き い誤差を与兄ることを示唆している，従って測定時に積 
Table 1 Influence of residual and noise currents for the data processing of peak polarogram

\begin{tabular}{|c|c|c|c|c|c|c|c|c|}
\hline \multicolumn{4}{|c|}{ Parameter } & & \multirow{2}{*}{ O* } & \multicolumn{3}{|c|}{ Result } \\
\hline$A$ & $B$ & $C$ & $P$ & Q & & $I_{\mathrm{p}}(\mathrm{nA})$ & $-E_{\mathrm{p}}(\mathrm{V})$ & $W_{\mathrm{p}}(\mathrm{mV})$ \\
\hline 0 & 0 & 0 & 0 & 0 & 2 & 999.999634 & 0.50000000 & 49.9999696 \\
\hline 0 & -1015 & 0 & 0 & 0 & 2 & 999.999635 & 0.50000000 & 49.9999696 \\
\hline 6600 & -1015 & 1000 & 0 & 0 & 2 & 999.999632 & 0.50000000 & 49.9999693 \\
\hline 6600 & 0 & 0 & 0 & 0 & 1 & 908.296312 & 0.50000000 & 43.5939910 \\
\hline 6600 & 0 & 0 & 0 & 0 & 2 & 999.999632 & 0.50000000 & 49.9999694 \\
\hline 6600 & 0 & 0 & 0 & 0 & 3 & 999.999632 & 0.50000000 & 49.9999694 \\
\hline 0 & 0 & 0 & 1 & 100 & 2 & $1003.05332(3.32)$ & $0.50002276(0.085)$ & $51.1924924(6.20)$ \\
\hline 0 & 0 & 0 & 0.1 & 100 & 2 & $1007.44882(1.53)$ & $0.50003099(0.025)$ & $50.5748974(2.88)$ \\
\hline 6600 & 0 & 0 & 1 & 100 & 2 & $965.065195(4.39)$ & $0.49987395(0.072)$ & $48.3166817(5.89)$ \\
\hline
\end{tabular}

Table 2 Reproducibility of the data processing for differential pulse polarography

\begin{tabular}{|c|c|c|c|c|c|c|c|c|c|}
\hline \multirow{3}{*}{$\begin{array}{l}\text { Exp. } \\
\text { No. }\end{array}$} & \multicolumn{6}{|c|}{ Computer } & \multirow{2}{*}{\multicolumn{3}{|c|}{ Manual }} \\
\hline & \multicolumn{3}{|c|}{ 1st approximation } & \multicolumn{3}{|c|}{ Rigorous treatment } & & & \\
\hline & $I_{\mathrm{p}}(\mathrm{nA})$ & $-E_{\mathrm{p}}(\mathrm{V})$ & $W_{\mathrm{p}}(\mathrm{mV})$ & $I_{\mathrm{p}}(\mathrm{nA})$ & $-E_{\mathrm{p}}(\mathrm{V})$ & $W_{\mathrm{p}}(\mathrm{mV})$ & $I_{\mathrm{p}}(\mathrm{nA})$ & $-E_{\mathrm{p}}(\mathrm{V})$ & $W_{\mathrm{p}}(\mathrm{mV})$ \\
\hline 1 & 43.7 & 0.617 & 55.2 & 43.3 & 0.617 & 57.3 & 46.1 & 0.609 & 54 \\
\hline 2 & 43.9 & 0.617 & 55.2 & 43.6 & 0.617 & 57.3 & 46.4 & 0.610 & 53 \\
\hline 3 & 44.1 & 0.617 & 64.4 & 44.2 & 0.613 & 59.4 & 46.1 & 0.605 & 60 \\
\hline 4 & 42.2 & 0.625 & 64.4 & 43.6 & 0.618 & 58.7 & 45.8 & 0.610 & 52 \\
\hline 5 & 43.2 & 0.617 & 55.2 & 42.7 & 0.618 & 57.6 & 45.5 & 0.609 & 53 \\
\hline 6 & 43.2 & 0.617 & 64.4 & 43.2 & 0.617 & 64.4 & 45.0 & 0.605 & 62 \\
\hline Mean & 43.4 & 0.618 & 59.8 & 43.4 & 0.617 & 59.1 & 45.8 & 0.608 & 55.7 \\
\hline $\operatorname{RSD}(\%)$ & 1.58 & 0.52 & 8.43 & 1.14 & 0.30 & 4.59 & 1.09 & 0.39 & 7.59 \\
\hline
\end{tabular}

$10 \mu \mathrm{M}$ pyrazine in Britton-Robinson buffer solution ( $\mathrm{pH} 4.0) ;$ Drop time $: 1 \mathrm{~s} ;$ Scan rate : $7.81 \mathrm{mV} / \mathrm{s} ;$ Pulse height : 39.1 mV; SCE: $25^{\circ} \mathrm{C}$

算平均又はノイズ除去プログラムを併用して，ノイズを 極力減衰させるのが得策と考えられる.

\section{3 測定及び解析処理の精度}

$10 \mu \mathrm{M}$ ピラジンを含む電解液で記録したポーラログラ ムについて, コンピューター解析と手解析の結果を比較 して Table 2 に示す. $I_{\mathrm{p}}, E_{\mathrm{p}}$ 及び $W_{\mathrm{p}}$ の再現性は, いずれの解析方法でも同程度であることが認められる. 又 ピラジンの濃度を（1〜50) $\mu \mathrm{M}$ の範囲で変化させた 場合, 濃度と $I_{\mathrm{p}}$ の間に 良好な直線関係（相関係数 : Manual 0.9992, 1st approximation 0.9992; Rigorous treatment 0.9991) が得られ，カーブフィッティング法 の変動係数は全濃度範囲を通じて $2 \%$ 程度であった.

$10 \mu \mathrm{M}$ 鉛，カドミウム，亜鉛イオンを含む 3 成分系に ついての解析結果を Table 3 に示す. シグモイド形ポ ーラログラムの場合 ${ }^{12)}$ と異なり，多成分系でも解析精度 の低下は認められなかった。 又，ノイズの少ない場合は 近似值 (1st approximation) も分析の目的に十分利用で きるものと考えられる. 解析時間は 1 波当たり約 1 分で あった。

\section{4 フィッティング関数についての考察}

以上の解析ではプログラムの簡単さと処理時間の関係 からフィッティング関数としてガウス関数（2）を用い る解析方法について考察した. しかし，ピークボルタン グラムはガウス関数とローレンツ関数（コーシー関数） の中間的な挙動を示すことが知られている ${ }^{16)}$. そこでガ ウス関数 (2), ローレンツ関数 (3) 及び理論式 ${ }^{20)}\{$ 式(4), 微分形 Heyrovský-Ilkovič 式\}を用いて解析を行い, 実測值（黒点）とフィッティング曲線（実線）を比較し て Fig. 4 に示す.

$$
\begin{aligned}
& Y\left(E_{\mathrm{i}}\right)=I_{\mathrm{p}} /\left[1+\left(E_{\mathrm{i}}-E_{\mathrm{p}}\right)^{2} /\left(W_{\mathrm{p}} / 2\right)^{2}\right] \cdots \\
& Y\left(E_{\mathrm{i}}\right)=\frac{4 I_{\mathrm{p}} \exp \left[3.50\left(E_{\mathrm{i}}-E_{\mathrm{p}}\right) / W_{\mathrm{p}}\right]}{\left\{1+\exp \left[3.50\left(E_{\mathrm{i}}-E_{\mathrm{p}}\right) / W_{\mathrm{p}}\right]\right\}^{2}} .
\end{aligned}
$$

式（4) において半值幅 $\left(W_{\mathrm{p}}\right)$ は $1.52 \times 2.303(R T /$ $n F)$ に対応する1).フィッティングの良さ (goodness of fit : $S^{2}{ }_{\text {fit }}$ ) は, 式 (5) を用いて求めた ${ }^{16)}$.

$$
S^{2}{ }_{\mathrm{fit}}=\sum_{\mathrm{i}}\left[Y_{\mathrm{i}}-Y\left(E_{\mathrm{i}}\right)\right]^{2} /(N-P)
$$

ここで, $N$ はデータ数 $(N=56), P$ はィッティンク 
Table 3 Comparison of computer and manual analyses for multi-step differential pulse polarograms

\begin{tabular}{|c|c|c|c|c|c|c|c|c|c|c|}
\hline \multirow{3}{*}{$\begin{array}{l}\text { Exp. } \\
\text { No. }\end{array}$} & & \multicolumn{6}{|c|}{ Computer } & & & \\
\hline & & \multicolumn{3}{|c|}{ 1st approximation } & \multicolumn{3}{|c|}{ Rigorous treatment } & \multicolumn{3}{|c|}{ Manual } \\
\hline & & $I_{\mathrm{p}}(\mathrm{nA})$ & $-E_{\mathrm{p}}(\mathrm{V})$ & $W_{\mathrm{p}}(\mathrm{mV})$ & $I_{\mathrm{p}}(\mathrm{nA})$ & $-E_{\mathrm{p}}(\mathrm{V})$ & $W_{\mathrm{p}}(\mathrm{mV})$ & $I_{\mathrm{p}}(\mathrm{nA})$ & $-E_{\mathrm{p}}(\mathrm{V})$ & $W_{\mathrm{p}}(\mathrm{mV})$ \\
\hline 1 & $\left\{\begin{array}{l}\mathrm{Pb} \\
\mathrm{Cd} \\
\mathrm{Zn}\end{array}\right.$ & $\begin{array}{l}81.5 \\
75.1 \\
72.8\end{array}$ & $\begin{array}{l}0.367 \\
0.578 \\
0.977\end{array}$ & $\begin{array}{l}58.3 \\
58.3 \\
58.3\end{array}$ & $\begin{array}{l}83.0 \\
75.4 \\
72.3\end{array}$ & $\begin{array}{l}0.362 \\
0.575 \\
0.975\end{array}$ & $\begin{array}{l}55.8 \\
53.2 \\
56.7\end{array}$ & $\begin{array}{l}86.1 \\
76.3 \\
74.5\end{array}$ & $\begin{array}{l}0.368 \\
0.574 \\
0.961\end{array}$ & $\begin{array}{l}62 \\
54 \\
52\end{array}$ \\
\hline 2 & $\left\{\begin{array}{l}\mathrm{Pb} \\
\mathrm{Cd} \\
\mathrm{Zn}\end{array}\right.$ & $\begin{array}{l}83.6 \\
74.9 \\
71.3\end{array}$ & $\begin{array}{l}0.367 \\
0.578 \\
0.977\end{array}$ & $\begin{array}{l}49.1 \\
49.1 \\
49.1\end{array}$ & $\begin{array}{l}83.6 \\
75.1 \\
71.0\end{array}$ & $\begin{array}{l}0.368 \\
0.577 \\
0.977\end{array}$ & $\begin{array}{l}52.5 \\
52.5 \\
55.3\end{array}$ & $\begin{array}{l}88.8 \\
77.5 \\
75.3\end{array}$ & $\begin{array}{l}0.369 \\
0.576 \\
0.964\end{array}$ & $\begin{array}{l}53 \\
53 \\
52\end{array}$ \\
\hline 3 & $\left\{\begin{array}{l}\mathrm{Pb} \\
\mathrm{Cd} \\
\mathrm{Zn}\end{array}\right.$ & $\begin{array}{l}84.8 \\
75.3 \\
72.5\end{array}$ & $\begin{array}{l}0.367 \\
0.570 \\
0.977\end{array}$ & $\begin{array}{l}58.3 \\
49.1 \\
58.3\end{array}$ & $\begin{array}{l}86.2 \\
75.6 \\
72.9\end{array}$ & $\begin{array}{l}0.362 \\
0.576 \\
0.973\end{array}$ & $\begin{array}{l}54.1 \\
52.5 \\
56.9\end{array}$ & $\begin{array}{l}88.8 \\
78.1 \\
75.0\end{array}$ & $\begin{array}{l}0.364 \\
0.564 \\
0.956\end{array}$ & $\begin{array}{l}55 \\
52 \\
60\end{array}$ \\
\hline 4 & $\left\{\begin{array}{l}\mathrm{Pb} \\
\mathrm{Cd} \\
\mathrm{Zn}\end{array}\right.$ & $\begin{array}{l}84.7 \\
76.0 \\
70.8\end{array}$ & $\begin{array}{l}0.367 \\
0.578 \\
0.984\end{array}$ & $\begin{array}{l}49.1 \\
49.0 \\
58.3\end{array}$ & $\begin{array}{l}84.7 \\
75.7 \\
72.9\end{array}$ & $\begin{array}{l}0.368 \\
0.578 \\
0.978\end{array}$ & $\begin{array}{l}52.5 \\
52.9 \\
56.9\end{array}$ & $\begin{array}{l}89.4 \\
78.1 \\
75.6\end{array}$ & $\begin{array}{l}0.371 \\
0.575 \\
0.964\end{array}$ & $\begin{array}{l}54 \\
53 \\
53\end{array}$ \\
\hline 5 & $\left\{\begin{array}{l}\mathrm{Pb} \\
\mathrm{Cd} \\
\mathrm{Zn}\end{array}\right.$ & $\begin{array}{l}85.3 \\
75.0 \\
71.4\end{array}$ & $\begin{array}{l}0.367 \\
0.570 \\
0.969\end{array}$ & $\begin{array}{l}58.3 \\
49.1 \\
49.1\end{array}$ & $\begin{array}{l}85.6 \\
75.0 \\
71.1\end{array}$ & $\begin{array}{l}0.364 \\
0.571 \\
0.970\end{array}$ & $\begin{array}{l}52.8 \\
51.3 \\
55.0\end{array}$ & $\begin{array}{l}88.8 \\
78.4 \\
76.1\end{array}$ & $\begin{array}{l}0.370 \\
0.565 \\
0.954\end{array}$ & $\begin{array}{l}55 \\
54 \\
53\end{array}$ \\
\hline Mean & $\left\{\begin{array}{l}\mathrm{Pb} \\
\mathrm{Cd} \\
\mathrm{Zn}\end{array}\right.$ & $\begin{array}{l}84.0 \\
75.3 \\
71.8\end{array}$ & $\begin{array}{l}0.367 \\
0.575 \\
0.977\end{array}$ & $\begin{array}{l}54.6 \\
50.9 \\
54.6\end{array}$ & $\begin{array}{l}84.6 \\
75.3 \\
72.0\end{array}$ & $\begin{array}{l}0.365 \\
0.575 \\
0.975\end{array}$ & $\begin{array}{l}53.5 \\
52.5 \\
56.2\end{array}$ & $\begin{array}{l}88.4 \\
77.7 \\
75.3\end{array}$ & $\begin{array}{l}0.368 \\
0.571 \\
0.960\end{array}$ & $\begin{array}{l}55.8 \\
53.2 \\
54.0\end{array}$ \\
\hline $\operatorname{RSD}(\%)$ & $\left\{\begin{array}{l}\mathrm{Pb} \\
\mathrm{Cd} \\
\mathrm{Zn}\end{array}\right.$ & $\begin{array}{l}1.84 \\
0.56 \\
1.23\end{array}$ & $\begin{array}{l}0.0 \\
0.76 \\
0.54\end{array}$ & $\begin{array}{l}9.22 \\
8.11 \\
9.31\end{array}$ & $\begin{array}{l}1.57 \\
0.43 \\
1.30\end{array}$ & $\begin{array}{l}0.83 \\
0.53 \\
0.33\end{array}$ & $\begin{array}{l}2.67 \\
1.38 \\
1.66\end{array}$ & $\begin{array}{l}1.49 \\
1.08 \\
0.81\end{array}$ & $\begin{array}{l}0.73 \\
1.02 \\
0.48\end{array}$ & $\begin{array}{l}6.39 \\
1.57 \\
6.28\end{array}$ \\
\hline
\end{tabular}

$10 \mu \mathrm{M} \mathrm{Pb}^{2+}, \mathrm{Cd}^{2+}$, and $\mathrm{Zn}^{2+}$ in $0.1 \mathrm{M} \mathrm{KGl}$; Drop time: $1 \mathrm{~s}$; Scan rate: $7.81 \mathrm{mV} / \mathrm{s}$; Pulse height : $39.1 \mathrm{mV}$; SCE: $25^{\circ} \mathrm{C}$
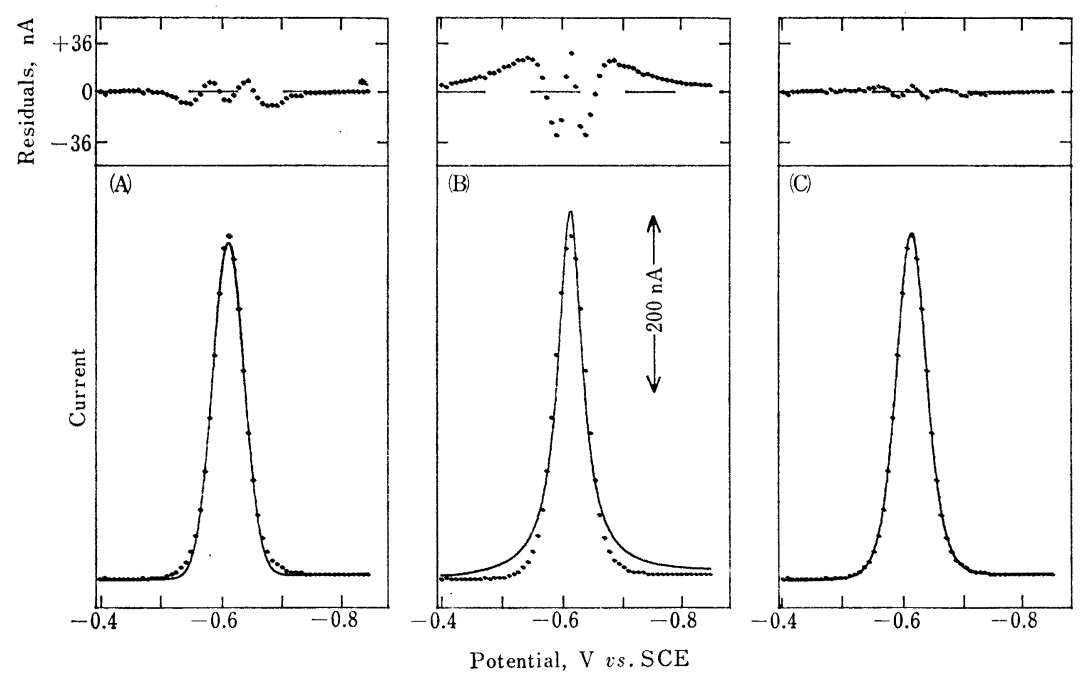

Fig. 4 Comparison of goodness of fit $\left(S_{\text {fit }}^{2}\right)$ and fitting time $\left(t_{\text {fit }}\right)$ with fitting functions

Blocks: Observed data; Line : Fit; $\quad 50 \mu \mathrm{M}$ pyrazine in Britton-Robinson buffer solution of pH 4.0; Drop time : $2 \mathrm{~s}$; Scan rate $: 7.81 \mathrm{mV} / \mathrm{s}$; Pulse height $: 39.1 \mathrm{mV}$; (A) Gaussian distribution, $S^{2} \mathrm{fit}=5.6, t_{\mathrm{fit}}=115 \mathrm{~s}$; (B) Lorentzian distribution, $S^{2} \mathrm{fit}=70.6, t_{\mathrm{fit}}=153 \mathrm{~s}$; (C) Theoretical equation, $S^{2} \mathrm{fit}=0.71, t_{\mathrm{fit}}=173 \mathrm{~s}$

パラメーター数 $(P=3)$ である.

フィッティング関数として式（4）を用いた場合, 最

良の結果が得られるがフィッティング時間 $\left(t_{\mathrm{fit}}\right)$ がや や長いのが欠点である. 式 (3) は最覀のフィッティン グ挙動を示し, 分析化学的応用は不適当と考学られる. 式（2）は，ピークの頂上部とすその部分でわずかな不 一致を示すが全体的に式（4）と類似した挙動が認めら れ，重複を示さないピークを用いる分析の目的には十分
利用できるものと考えられる.

\section{4 結 論}

比較的安価な 2 台のマイコンを用いる電解測定及びデ 一タ処理システムを試作し, 微分パルスポーラログラフ ィーのための装置制御及びカーブフィッティング法によ るデータ処理プログラムを開発した. バックグラウンド 電流及びノイズを含む電流電位曲線をコンピューターで 
合成し, バックグラウンド電流の補正方法及び解析に及 ぼすノイズの影響について基礎的検討を行い，2次多項 式を用いるフィッティング法が良い結果を与えることを 明らかにした. 又, 単成分及び 3 成分系について微分ハ ルスポーラログラムを記録し，コンピューター解析の実 用性について考察した. 更に, フィッティング関数（ガ ウス関数, ローレンツ関数, ポーラログラフィーの理論 式）について比較検討を行い, 理論式が最良の結果を与 えることを, 又, ガウス関数も十分実用に耐えらること を明らかにした。

$\left(\begin{array}{l}1980 \text { 年 } 4 \text { 月，日本化学会筙 } \\ 41 \text { 春季年会において一部発表 }\end{array}\right)$

\section{交献}

1) A. M. Bond : "Modern Polarographic Methods in Analytical Chemistry", (1980), (Dekker, New York).

2) P. Barrett, L. J. Davidowski, T. R. Copeland : Anal. Chim. Acta, 122, 67 (1980).

3) H. E. Keller, R. A. Osteryoung : Anal. Chem., 43, 342 (1971).

4) M. Bos : Anal. Chim. Acta, 81, 21 (1976). ibid., 103, 367 (1978).

5) A. M. Bond, B. S. Grabaric : Anal. Chem., 51, 126 (1979).

6) A. M. Bond, B. S. Grabaric : Anal. Chim. Acta, 101, 309 (1978).

7) H. J. Skov, L. Kryger : Anal. Chim. Acta, 122, 179 (1980).

8) E. B. Buchanan, Jr., W. J. Sheleski : Talanta, 27, 955 (1980).

9) T. E. Edmonds : Anal. Chim. Acta, 108, 155 (1979).

10) J. E. Anderson, A. M. Bond : Anal. Chem., 53, 504 (1981).

11) O. M. Evans, K. W. Hanck : Anal. Chim. Acta, 129, 79 (1981).

12) 和佐 保, 山本 弘: 分化, 31, T55 (1982).

13) 佐藤 弦, 池内温子: 電化, 48, 157 (1980).

14）横井与次郎：“リニア IC 実用回路マニュアル”, p. 67 (1975)，（ラジオ技術社).

15) T. E. Cummings, J. R. Fraser, P. J. Elving : Anal. Chem., 52, 558 (1980).

16) P. A. Boudreau, S. P. Perone : Anal. Chem., 51, 811 (1979).

17) A. M. Bond, B. S. Grabaric : Anal. Chem., 51, 337 (1979).

18） T. R. McCalla 著, 三浦 功, 田尾陽一訳 : “計 算機のための数值計算法概論”， p. 225 (1972), (サイエンス社).
19) P. R. Bevington : "Data Reduction and Error Analysis for the Physical Sciences", p. 204 (1969), (McGraw-Hill, New York).

20) A. M. Bond, R. J. O'Halloran : J. Electroanal. Chem., 68, 257 (1976).

$$
\text { 角 }
$$

Differential pulse polarography and its data processing with a microcomputer-controlled electroanalytical system. Tamotsu WASA, Hiroshi Үамамото, and Kengo Акімото (Department of Applied Chemistry, College of Engineering, University of Osaka Prefecture, 4-804, Mozu-Umemachi, Sakaishi, Osaka)

A microcomputer-controlled electroanalytical system by using two microcomputers (MEK DII, Motorola and H68/TR, Hitachi), potentiostat and current measuring circuit was constructed and programs of the system control and the data processing for differential pulse polarography have been developed. The system control program coded by machine language of MEK DII was almost the same as that of sigmoidal polarography, except for addition of data-averaging and noise-eliminating sub-programs. The outline of the data-processing program coded by BASIC language of H68/TR is as follows: after smoothing of the data transferred from MEK DII, peak potential $\left(E_{\mathrm{p}}\right)$, halfpeak width $\left(W_{\mathrm{p}}\right)$, and regions of peak and background were determined by comparing currents and the slopes of the $i-E$ curve. Peak current $\left(I_{\mathrm{p}}\right)$ was then estimated by the correction of background current, obtained by using the least-squares fitting with the quadratic polynominal for the background regions. Finally, approximate values were utilized for the rigorous calculation of $I_{\mathrm{p}}, E_{\mathrm{p}}$, and $W_{\mathrm{p}}$ by means of least-squares fitting with Gaussian equation. The results of dataprocessing by computer were in good agreement with those obtained by manual treatment. The overall precision of the system for the determination of $10 \mu \mathrm{M}-$ level depolarizers (pyrazine, $\mathrm{Pb}^{2+}, \mathrm{Cd}^{2+}, \mathrm{Zn}^{2+}$ etc.) was within $\pm 2 \%$ for $I_{\mathrm{p}}, \pm 1 \%$ for $E_{\mathrm{p}}$, and $\pm 5 \%$ for $W_{\mathrm{p}}$ and the execution time was about $1 \mathrm{~min} /$ peak. Applicability of the fitting functions such as theoretical, Gaussian, and Lorentzian equations was briefly examined.

(Received July 26, 1982)

\section{Keyword phrases}

differential pulse polarography with microcomputercontrolled electroanalytical system; data-processing system for differential pulse polarography; leastsquares fitting for peak polarogram; background correction. 